\title{
Mycoflora, Mycotoxin Contamination and Proximate Mineral Composition of Smoke-Dried Frog (Aubria sp.) (Konko) Sold in Ibadan, Oyo State, Nigeria
}

\author{
Bukola Adebayo-Tayo*, Folahanmi Adeyemi, Olubusola Odeniyi, Kayode Olaseinde
}

Department of Microbiology, Faculty of Science, University of Ibadan, Ibadan, Oyo State, Nigeria

\section{A R T I C LE IN F O}

\section{Article history:}

Received 29 June 2015

Accepted 05 November 2015

Available online, ISSN: 2148-127X

\section{Keywords:}

Smoked-dried frog

Aflatoxin

Deoxynivalenol

Fungi

${ }^{*}$ Corresponding Author:

E-mail: bukola.tayo@gmail.com
A B S T R A C T

Mycoflora, mycotoxin contamination and proximate mineral composition of smokeddried frog (Aubria sp.) samples purchased from different markets in Ibadan, Oyo State were investigated. A total of 20 composite samples made up of 120 smoked-dried frog samples were collected. The total fungi count ranged from $1.0 \times 10^{3}-8.0 \times 10^{3} \mathrm{cfu} / \mathrm{g}$. A total of 70 fungal strains including: Alternaria sp., Aspergillus flavus, Aspergillus niger, Aspergillus tamarii, Cladosporium sphaerospermum, Fusarium compacticum, Fusarium oxysporum, Fusarium sacchari, Fusarium solani, Fusarium verticillioides, Penicillium chrysogenum, Penicillium citrinum, Penicillium oxalicum, Trichoderma viridae and Rhizophus sp. were isolated from the samples. All the samples were contaminated with aflatoxin and $70 \%$ were contaminated with deoxynivalenol (DON). The total Aflatoxin and DON in the two sampling ranged from $5.06^{\mathrm{h}}-9.17^{\mathrm{a}} \mathrm{ppb}, 1.86^{\mathrm{h}}-5.58^{\mathrm{a}} \mathrm{ppb}$ and $0.00-$ $0.96 \mathrm{ppm}$ and $0.00-0.09 \mathrm{ppm}$. The levels of mycotoxins contamination were within the maximum limit permitted. The Aspergillus flavus and Fusarium spp. were able to produce aflatoxin and DON which ranged from $1.65-3.56 \mathrm{ppb}$ and $0.05-0.19 \mathrm{ppm}$. The percentage crude protein, $\mathrm{K}, \mathrm{Ca}$ and $\mathrm{Fe}$ content in the samples ranged from $40.79^{\mathrm{j}}$ $53.93^{\mathrm{a}}, \quad 217.85-1235.83 \mathrm{mg} / 100 \mathrm{~g}, 4201-437.25 \mathrm{mg} / 100 \mathrm{~g}$ and $431.75-1065.0$ $\mathrm{mg} / 100 \mathrm{~g}$. The moisture content ranged from $11.58^{\mathrm{h}}-16.31^{\mathrm{a}}$. The $\mathrm{Cd}, \mathrm{Zn}$ and $\mathrm{Cu}$ content ranged from $0.00-0.22 \mathrm{mg} / 100 \mathrm{~g}, 9.43-5.20 \mathrm{mg} / 100 \mathrm{~g}$ and $7.05-18.58 \mathrm{mg} / 100 \mathrm{~g}$. The presence of mycotoxigenic fungi and mycotoxin levels in the dried frog samples is of public health concern and proper attention is needed for the control of quality and adequate preservation before sales and consumption.

\section{Introduction}

Animal protein in developing countries has over the years been in shortage supply, which has been attributed to inadequate products and high cost of conventional sources of animal protein-poultry, goat meat, beef, mutton and pork. This has led to the sourcing of alternatives to provide a solution to this problem of reduction of conventional meat, which has resulted in the increase in consumption of other meats. Frogs are consumed in some part of the world as source of protein. These amphibians are obtained in different forms such as fresh, sun dried, smoked, and smoked-dried; a process in which the frog is treated by combined smoking and drying steps to such an extent that refrigeration can be avoided, etc. The legs are considered by many to be a delicacy and have been collected on a local scale as an essential source of animal protein (Mohneke et al., 2009). The smoked-dried frog sample identified to be Aubria sp, also known as West African brown frog; this genus is closely related to the genus Rana sp. A stocky frog with a dark brown back and a relatively visible tympanium. The underside is usually speckled white over a brown background.

Microorganisms are ubiquitous and our food including smoked-dried frogs is not exempted. Food items could easily be contaminated with microorganisms in the environment, during handling and during processing. The food could also serve as a medium for the growth of the microorganisms after contamination. Microorganisms could change the nature of the food resulting to spoilage and food poisoning (Pelczar et al., 1993). Moulds are multicellular fungi that form thin thread like structures called hyphae. They are widely distributed and found wherever moisture is present (Wiley et al., 2008). Fungi 
are major spoilage of foods and feedstuffs. The proliferation of various fungi in agricultural products leads to reduction in yield and quality with significant economic losses (Bankole, 1994). They produce secondary metabolites which are referred to as mycotoxins which have been found to be present in most food substances. The mycotoxins are low weight metabolites which cause harm known as mycotoxicoses, in livestock, domestic animals and humans and therefore of public health significance (Bhat and Vasanthi, 2003).The production of mycotoxins is stimulated by certain environmental factors: therefore the extent of contamination will differ with geographic location, agricultural methods and the susceptibility of commodities to the penetration of fungi during storage and processing periods (Jonathan and Esho, 2010). Fungi that produce toxins in food are therefore classified into field fungi and storage fungi based on their ecological requirements for growth (Pelczar et al., 1993). Mycotoxins have also been reported in similar proteinous products such as smoked-dried fish and in dried meats (Adebayo-Tayo et al., 2008; Oladejo and Adebayo-Tayo, 2011).

Due to lack of awareness of the dangers posed by mycotoxins in alternative sources of animal protein, especially frog there is need for detailed assessment of their mycological quality and mycotoxins level and no study has been done on smoked-dried frogs in Nigeria.

The aim of the current work is to isolate and identify fungi associated with smoke-dried frogs sold in markets in Ibadan, Nigeria and to detect the mycotoxigenic fungi and to determine the presence and level of mycotoxins in the samples.

\section{Materials and Methods}

\section{Sample Collection}

Smoked dried frogs were purchased from retail stands in different major markets sites which were Bodija, Oje, Itamerin, Oja Oba, Aleshinloye and Moniya in Ibadan, Oyo State, Nigeria. Six samples of the smoked dried frogs were grouped together to make 20 composite totalling 120 in all. The samples were obtained July- October 2014, the first sampling was carried out in July and the second sampling was carried out in September and October. They were subsequently packaged in sterile polyethylene bags labelled properly and taken to the laboratory for analyses.

\section{Isolation and Characterization of Fungi Associated With the Samples}

Isolation of fungi from the smoke-dried frog samples were made on sterile Potato dextrose agar (PDA). The frog samples were individually ground in a common household blender. The blender's cup was rinsed with $85 \%$ alcohol between samples. Ten grams of the frog samples obtained from each of the markets were weighed aseptically into $90 \mathrm{~mL}$ sterile distilled water. From this, subsequent tenfold dilution was made up to $10^{-3}$. One millilitre of each dilution was dispensed in duplicate in sterile Petri dishes. Molten PDA to which streptomycin had been incorporated was added to the Petri dishes, which were gently rotated to ensure even dispersion. The plates were allowed to solidify and were incubated at $28 \pm 1^{\circ} \mathrm{C}$ for 3-7 days.

Discrete colonies were isolated in pure culture by subculturing the cells. Fungal isolates were identified based on their morphological and cultural characteristics as recommended by Domsch and Gams (1980) and Singh et al. (1991).

\section{Determination of Aflatoxigenic Fungi}

Determination of aflatoxigenic fungi was carried out using the method of Davis et al., (1987). Pure fungal isolates were cultured on Coconut Agar Medium (CAM). The plates were incubated for 3 days at $28^{\circ} \mathrm{C}$.Production of an orange-yellow pigmentation by the mycelium was observed for toxigenic isolates prior to the production of blue fluorescence on the reverse side of the colony under UV light (365nm).

Toxigenic fungal isolates were also determined using a modified method of Atanda et al., (2006). Pure matured fungal isolates were cultured on Palm Kernel Agar (PKA). Aflatoxigenic fungi were detected by the production of yellow pigmentation and a blue fluorescence of agar under UV light (365 nm).

\section{Determination of Mycotoxins in the Samples}

Quantitative determination of total aflatoxin and deoxynivalenol in smoked dried frog sample using Enzyme Linked Immunosorbent Assay (ELISA). The mycotoxins analysis were carried out using commercially available immunoassay kit Veratox test-NEOGEN Crop, Lansing, MI was used.

\section{Sample preparation and extraction}

The collected samples (smoked-dried frogs) were ground into powdery form with the use of high speed blender, thoroughly mixed together and made into composite, followed by weighing on an electronic scale. Five grams of smoke-dried frog was put into an extraction cup. $25 \mathrm{~mL}$ of $70 \%$ methanol was added for aflatoxin, while $25 \mathrm{~mL}$ of sterile distilled water was added for the deoxynivalenol, the extraction cup was covered and manually shaken for 3 minutes; the mixture was then allowed to settle down. The extract was filtered by pouring $5 \mathrm{~mL}$ through a whatman filter syringe, and filtrate was collected for further analysis.

\section{Test Procedure}

The number of dilution strips required for both the samples and the standards were placed in a microwell strip holder. Equal numbers of antibody coated strip were also placed in a microwell strip holder. Using a multipurpose channel pippettor $100 \mu \mathrm{L}$ of the conjugate was introduced into each of the dilution well. $100 \mu \mathrm{L}$ of the sample were placed in the dilution well containing the conjugate base. The multipurpose pippettor was used to mix the sample by carefully pipetting it upwards and downwards three times. $100 \mu \mathrm{L}$ of the mixture was immediately transferred into antibody coated plate and 
incubated for 5 minutes at room temperature. The antibody coated plates were later decanted and washed five times with distilled water. $100 \mu \mathrm{L}$ portion of the substrate was then put into the antibody coated plate and incubated. A stop solution of $100 \mu \mathrm{L}$ was introduced into each antibody coated plate. The microwell strips were subsequently analysed using a microwell reader using a $630 \mathrm{~nm}$ filter. Concentration of mycotoxins was read and calculated using Neogen's Veratox software.

Concentration and Production of Aflatoxin By Aspergillus Species and Deoxynivalenol (DON) By Fusarium Species.

Aspergillus and Fusarium isolates identified on PDA were sub cultured in duplicate on YESA consisting of (Yeast extract $4.0 \mathrm{~g}, \mathrm{KH}_{2} \mathrm{PO}_{4} 1 \mathrm{~g}, \mathrm{MgSO} 4.7 \mathrm{H}_{2} \mathrm{O} 0.5 \mathrm{~g}$, sucrose $20.0 \mathrm{~g}$ and agar $15 \mathrm{~g}$ per litre) and incubated at $28^{\circ} \mathrm{C}$ for 21 days to evaluate the aflatoxin and Deoxynivalenol production (Kana et al., 2013). Aflatoxin and Deoxynivalenol was extracted from approximately 5 $\mathrm{g}$ of YESA with fungi colonies in $25 \mathrm{~mL}$ of $70 \%$ methanol and sterile distilled water respectively using the standard ELISA extraction protocol essentially described by the kit manufacturer (NEOGEN Crop, Lansing, MI., USA). Aflatoxin and Deoxynivalenol was quantified using ELISA KIT (Veratox for quantitative analysis of total aflatoxin and Deoxynivalenol test-NEOGEN Crop, Lansing, MI).

Determination of Proximate mineral Composition of the Samples

Proximate mineral analyses were carried out using AOAC (1990) methods which included protein determination, fat extraction, crude fibre determination and moisture.

\section{Data Analysis}

The data generated from the investigations were subjected to statistical analysis using SPSS 20, Duncan multiple range test was used to compare significant differences between the means.

\section{Results and Discussion}

The total fungi count ranged from $1.0 \times 10^{3}-8.0 \times$ $10^{3} \mathrm{cfu} / \mathrm{g}$ in which the highest was recorded in samples obtained from samples from Itamerin Market (1 Itam a). 16 of the samples $(80 \%)$ were found to have total fungi count of $\leq 3.0 \times 10^{3} \mathrm{cfu} / \mathrm{g}$ while only four samples $(20 \%)$ were found to have total fungi count of $\geq 3.0 \times 10^{3} \mathrm{cfu} / \mathrm{g}$ as shown in Table 1.

A total of 70 fungi strains were obtained from the smoke dried frog samples. The fungi were identified as Alternaria sp, Aspergillus flavus, Aspergillus niger, Aspergilus tamarri, Cladosporium sphaerospermum, Fusarium compacticum, Fusarium oxysporum, Fusarium solani, Fusarium verticillioides, Fusarium sacchari, Penicilium chrysogenum, Penicillium citrinin, Penicillium oxalicum, Trichoderma viridae and Rhizophus sp (Table 2)
Table 3 shows the fungi associated with smoked dried frogs samples collected at different month interval had Penicillium citrinumas the most distributed, isolated from the six markets. Aspergillus niger and Fusarium oxysporum were also predominantly distributed in the samples obtained from the markets. Aspergillus niger was isolated from Bodija, Oja Oba, Itamerin, Moniya and Fusarium oxysporum was isolated from Oje, Itamerin, Aleshinloye and Moniya. On the other hand Cladosporium sphaerospermum and Alternaria spwere isolated the least from the samples.

Different fungal strains were isolated from the samples which are of major public health concern. A major public health risk with long term health implication is the contamination of food and feed (Bucci et al., 1990). The low water activity as a result of smoke-drying reduces the competitive effects of most bacteria. Several physical factors including moisture, humidity, ambient temperature, storage time, $\mathrm{pH}$ and oxygen affect fungal growth and mycotoxins production (Kaaya et al., 2006). Majority of the fungal organisms isolated and identified are widely distributed in nature and have their habitat mostly in the soil and decaying matter (Raper and Fennell 1965). They are able to contaminate food and cause infection.

Fifteen different fungal species were isolated from the smoked-dried frog samples viz., Alternaria $s p$, Aspergillus flavus, Aspergillus niger, Aspergillus tamarii, Cladosporium sphaerospermum, Fusarium compacticum, Fusarium oxysporum, Fusarium sacchari, Fusarium solani, Fusarium verticillioides, Penicillium chrysogenum, Penicillium citrinum, Penicillium oxalicum, Trichoderma viridae, Rhizophus sp.

Table 1 Total fungi count $\left(\times 10^{3} \mathrm{cfu} / \mathrm{g}\right)$ of the smoked-dried frog samples (Aubria sp.) obtained from different markets in Ibadan

\begin{tabular}{|c|c|c|}
\hline Source & Sample Code & TFC* \\
\hline \multirow{2}{*}{ Bodija } & $1 \mathrm{Bod}$ & 3.0 \\
\hline & 2 Bod & 3.0 \\
\hline \multirow{2}{*}{ Oja Oba } & $1 \mathrm{Oja}$ & 2.0 \\
\hline & $2 \mathrm{Oja}$ & 1.0 \\
\hline \multirow{2}{*}{ Oje } & $1 \mathrm{Oje}$ & 2.0 \\
\hline & $2 \mathrm{Oje}$ & 3.0 \\
\hline \multirow{2}{*}{ Itamerin A } & 1 Itam a & 8.0 \\
\hline & 2 Itam a & 2.0 \\
\hline \multirow{2}{*}{ Itamerin B } & 1 Itam b & 1.0 \\
\hline & 2 Itam b & 2.0 \\
\hline \multirow{2}{*}{ Aleshinloye A } & 1 Alesh a & 2.0 \\
\hline & 2 Alesh a & 1.0 \\
\hline \multirow{2}{*}{ Aleshinloye B } & 1 Alesh b & 2.0 \\
\hline & 2 Aleshb & 1.0 \\
\hline \multirow{2}{*}{ Aleshinloye C } & 1 Alesh c & 2.0 \\
\hline & 2 Alesh c & 2.0 \\
\hline \multirow{2}{*}{ Moniya A } & 1 Mon a & 2.0 \\
\hline & 2 Mon a & 1.0 \\
\hline \multirow{2}{*}{ Moniya B } & 1 Mon b & 2.0 \\
\hline & 2 Mon b & 2.0 \\
\hline
\end{tabular}

*Total Fungal Count $\left(\times 10^{3} \mathrm{cfu} / \mathrm{g}\right)$ 
Table 2 Colonial morphology and microscopic observation of fungi strains isolated from smoked-dried frog samples

\begin{tabular}{|c|c|c|c|c|}
\hline Growth & Colony Colour & $\mathrm{CH}^{*}$ & Conidial Head & Probable Organism \\
\hline Moderate & Blackish grey & Septate & Ovoid & Alternaria sp. \\
\hline Rapid & Yellowish green, golden yellow edges & Septate & Globose & Aspergillus flavus \\
\hline Rapid & $\begin{array}{l}\text { Blackish-Brown, sometimes first white to } \\
\text { yellow }\end{array}$ & Septate & Globose & Aspergillus niger \\
\hline Moderate & Rusty brown, with creamish brown reverse & Septate & Globose & Aspergillus tamarii \\
\hline Moderate & Light green velvety to powdery & Septate & Erect, cyclindrical & $\begin{array}{l}\text { Cladosporium } \\
\text { sphaerospermum }\end{array}$ \\
\hline Moderate & Whitish-cream & Septate & Ellipsoidal & Fusarium compacticum \\
\hline Rapid & White & Septate & Slightly curved & Fusarium oxysporum \\
\hline Moderate & Whitish cream with pale reverse & Septate & $\begin{array}{l}\text { Moderately } \\
\text { curved }\end{array}$ & Fusarium sacchari \\
\hline Moderate & Light greyish yellow & Septate & Slightly curved & Fusarium solani \\
\hline Moderate & $\begin{array}{l}\text { Creamish with pinkish pigmentation which } \\
\text { changes peach with age }\end{array}$ & Septate & Curved & Fusarium verticillioides \\
\hline Rapid & Green & Septate & Ellipsoidal & Penicillium chrysogenum \\
\hline Rapid & Dark greyish green and cream reverse & Septate & Spherical & Penicillium citrinum \\
\hline Rapid & Dark green, cream yellow reverse & Smooth & Ellipsoidal & Penicillium oxalicum \\
\hline Rapid & Greenish white with light green reverse & Sepate & Ellipsoidal & Trichoderma viridae \\
\hline Rapid & Whitish with black spores & Non septate & Spherical & Rhizophus sp. \\
\hline
\end{tabular}

*CH: Character of Hyphae

Table 3 Fungi strains associated with the smoked-dried frog (Aubria sp.) samples obtained from different markets in Ibadan.

\begin{tabular}{|c|c|c|c|c|c|c|c|c|c|c|}
\hline \multirow{2}{*}{ Fungal strains } & \multicolumn{10}{|c|}{ Markets } \\
\hline & $\mathrm{Bo}^{1}$ & $\mathrm{Oj}^{2}$ & $\mathrm{O}^{3}$ & It $^{3}$ & $\mathrm{ItB}^{4}$ & $\mathrm{AlA}^{5}$ & $\mathrm{AlB}^{6}$ & $\mathrm{AlC}^{7}$ & $\mathrm{MoA}^{8}$ & $\mathrm{MoB}^{9}$ \\
\hline Alternaria sp. & - & - & - & - & - & - & - & - & - & + \\
\hline Aspergillus flavus & + & - & - & + & + & - & - & + & + & + \\
\hline Aspergillus niger & + & + & - & + & - & - & - & - & + & + \\
\hline Aspergillus tamarii & - & + & - & - & - & + & - & - & - & - \\
\hline Cladosporum sphaerospermum & - & - & - & - & - & - & - & + & - & - \\
\hline Fusarium compactum & + & - & - & - & - & + & - & + & + & - \\
\hline Fusarium oxysporum & - & - & + & + & + & + & - & + & - & + \\
\hline Fusarium solani & - & + & - & - & - & - & - & + & - & - \\
\hline Fusarium verticilloides & - & - & + & - & - & - & + & + & - & - \\
\hline Fusarium sacchari & - & - & - & - & - & + & + & - & - & - \\
\hline Penicillium citrinum & + & + & + & - & + & - & + & - & - & + \\
\hline Penicillium oxalicum & - & - & - & + & - & - & - & + & - & + \\
\hline Penicillium chrysogenum & - & - & - & - & - & - & - & - & - & + \\
\hline Trichoderma viridae & - & - & - & - & - & + & - & + & + & + \\
\hline Rhizophus sp & - & - & - & - & - & - & + & - & + & - \\
\hline
\end{tabular}

+ present, - absent; $\mathrm{Bo}^{1}$ : Bodija; $\mathrm{Oj}^{2}$ : Oja Oba; $\mathrm{O}^{3}:$ Oje; $\mathrm{ItA}^{3}$ : Itamerin $\mathrm{A} ; \mathrm{ItB}^{4}$ : Itamerin $\mathrm{B} ; \mathrm{AlA}^{5}$ : Aleshinloye $\mathrm{A} ; \mathrm{AlB}^{6}$ : Aleshinloye $\mathrm{B} ; \mathrm{AlC}^{7}$ : Aleshinloye $\mathrm{C} ; \mathrm{MoA}^{8}$ : Moniya A; $\mathrm{MoB}^{9}$ : Moniya B

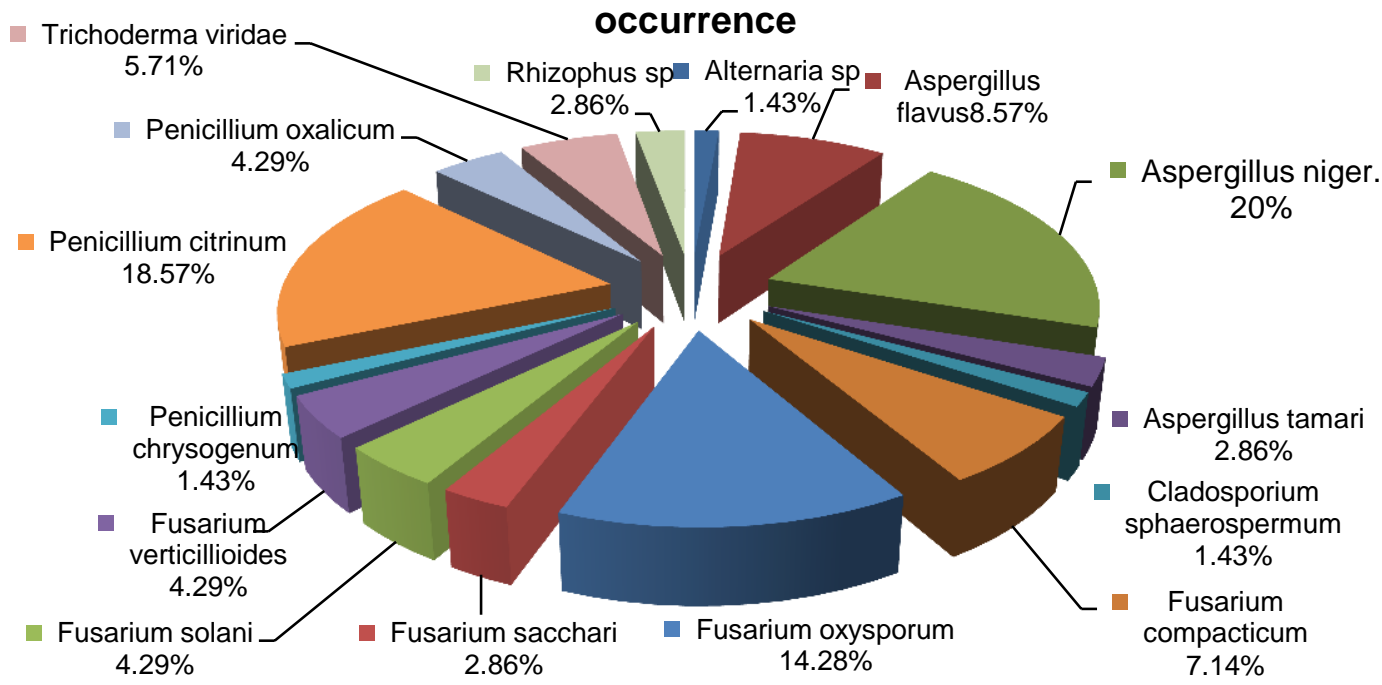

Figure 1 The fungal isolates and their frequency of occurrence $(\%)$ 
Figure 1 shows the frequency of occurrence of the isolates in which Aspergillus niger had the highest frequency of occurrence $(20 \%)$, followed in order by Penicillium citrinum (18.57\%), Fusarium oxysporum (14.28), Aspergillus flavus (8.57), Fusarium compactum (7.14), Trichoderma viridae (5.71\%), Fusarium solani, Fusarium verticillioides and Penicillium oxalicum had even occurrence of (4.29\%), Aspergillus tamarri, Fusarium sacchari and Rhizophus sp had even occurrence of $(2.86 \%)$ and Alternaria sp, Cladosporium sphaerospermum, Penicillium chrysogenum with (1.43\%) respectively.

The isolation of these genera in the samples agrees with the findings of some researchers who isolated similar organisms from smoked-dried fish, dried meats, rice, 'garri', and peanut meal and maize (Adebayo-Tayo et al., 2008; Somorin and Bankole 2010; Oladejo and AdebayoTayo 2011; Kana et al., 2013; Jonathan et al., 2013).

The isolated fungi can be classified as storage fungi and field fungi. The field fungi isolated were Fusarium oxysporum, Fusarium compacticum, Fusarium verticillioides, Fusarium solani, Fusarium sacchari, Cladopsorium sphaerospermum. The environmental requirements for the growth of the field fungi are different; the field fungi are eliminated during storage and the population of storage fungi increases (Bankole and Adebanjo 2003). The storage fungi could have contaminated the smoked-dried frog samples during any of the phases of processing. The storage fungi includes Aspergillus niger, Aspergillus flavus, Aspergillus tamarii, the others are Penicillium chrysogenum, Penicillium citrinum, Penicllium oxalicum, Rhizopus sp. The fungal species that colonize the smoked-dried frog sample must have been present in the atmosphere in the form of spores during the processing or gained entrance during storage period as a result of inadequate storage facilities as well as in the market and also during transportation. Majority of these smoked-dried frog samples are kept close to agricultural commodities which are more susceptible to fungal contamination and mycotoxins production and therefore there is also cross contamination. Postprocessing handling of smoked protein products is not properly done. The smoked-dried frogs were observed to be put on dirty sacks on the floor at the markets. They are stored in poorly ventilated and generally dirty environment, where houseflies contaminate them very much with dirt from the surrounding environment. They were also seen to be displayed in some markets near heaps of garbage and litters all over. Eyo (1992) reported that the handling of smoked product like fish are prone to microbial attack especially due to unhygienic methods during the smoke drying period, smoking kilns used in artisanal fishery and the overloading of the fishes on trays leads to improper processing which in turn encourages fungal attack.

Aflatoxigenic fungi isolated from the smoked-dried frogs samples obtained from different market in Ibadan were detected using Coconut Agar Medium (CAM) and Palm Kernel Agar (PKA) Medium. All Aspergillus flavus strains showed to be capable of producing aflatoxins, with the production of orange yellow pigmentation in the medium as shown in Table 4.

Table 5 shows the detection and quantification of total aflatoxin in the smoked dried-frog samples obtained from different markets in Ibadan. Aflatoxin was detected in all the smoked-dried samples and the aflatoxin ranged from $1.86-9.17 \mathrm{ppb}$. The highest concentration was recorded in the smoked-dried frog sample obtained from Aleshinloye $\mathrm{C}$ and the lowest concentration was recorded in the smoked-dried sample obtained from Itamerin A.

Table 6 shows the detection and quantification of deoxynivalenol (DON) in parts per million (ppm) in Smoked-dried frog samples obtained from different market in Ibadan showed $70 \%$ of the samples to be contaminated with deoxynivalenol. The deoxynivalenol concentration in the contaminated sample ranged from $0.01-0.96 \mathrm{ppm}$. The highest DON concentration was recorded in the smoked-dried frog samples obtained from the first sampling from Aleshinloye B. DON was not detected in some of the samples.

The production and concentration of Aflatoxin by Aspergillus flavus isolated from smoked-dried frog samples in Ibadan showed that all the Aspegillus flavus produced aflatoxin which indicates they are all toxigenic strains of Aspergillus flavus. The highest concentration was recorded in the isolate code 'BOD 4' having $3.56 \mathrm{ppb}$ obtained from Bodija as shown in Table 7.

The Fusarium spp were assayed for the production and concentration of deoxynivalenol. Some of the Fusarium spp produced DON. The highest concentration was recorded in the isolate code 'ALH 1' which had 0.30 ppm (Table 8).

The smoked foods are also consumed besides been is source of protein and also due to flavour and texture that the frog or fish or other smoked product acquires on smoking.

Aspergillus is a group of moulds that is found worldwide. Their potential for contamination of food stuffs and animal feeds is widespread under favourable environmental conditions. The genus Aspergillus is a large proportion of all the moulds found in industrial food (Onions et al., 1981). They have particular importance as spoilage organisms of food. Changes due to spoilage by Aspergillus species can be sensorial, nutritional and qualitative nature like pigmentation, discoloration, rotting development of off odours and off flavours. Many species grow at very low water activity and are found attacking various foods and producing mycotoxins (Lee et al., 2004). Aspergillus niger are worldwide distributed occurring on a great variety of substrates, is also the most common species of Aspergillus and responsible for postharvest decay (Pitt et al., 2000).

Penicillium is another group of mould with high occurrence. Occurrence of Penicillium in some samples during this investigation is in agreement with the report Barbosa et al. (2013). He reported high occurrence of Penicillium species from fish feed obtained from farm with Penicillium citrinum having the highest occurrence. Many of Penicillium species can also produce a wide range of toxic compounds such as citrin and citreoviridin (Barbosa et al., 2013). 
Table 4 Detection of aflatoxigenic fungi from smoked-dried frog samples (Aubria sp.) obtained from different markets in Ibadan

\begin{tabular}{|c|c|c|c|c|}
\hline \multirow{2}{*}{ Source } & \multirow{2}{*}{ Isolate code } & \multirow{2}{*}{ Fungus strains } & \multicolumn{2}{|c|}{ Detection media } \\
\hline & & & PKA & CAM \\
\hline \multirow{5}{*}{ Bodija Market } & BOD 1 & P. citrinium & - & - \\
\hline & BOD 2 & F. compacticum & - & - \\
\hline & BOD 3 & A. niger & - & - \\
\hline & BOD 4 & A. flavus & + & + \\
\hline & BOD 5 & P. citrinum & - & - \\
\hline \multirow{6}{*}{ Oja Oba Market } & OJB 1 & P. citrinum & - & - \\
\hline & OJB 2 & F. solani & - & - \\
\hline & OJB 3 & A. tamarii & - & - \\
\hline & OJB 4 & A. niger & - & - \\
\hline & OJB 5 & P. citrinum & - & - \\
\hline & OJB 6 & P. citrinum & - & - \\
\hline \multirow{3}{*}{ Oje Market } & OJE 1 & F. oxysporum & - & - \\
\hline & OJE 2 & F. verticillioides & - & - \\
\hline & OJE 3 & P. citrinum & - & - \\
\hline \multirow{11}{*}{ Itamerin Market } & ITM 1 & A. flavus & + & + \\
\hline & ITM 2 & A. niger & - & - \\
\hline & ITM 3 & F. oxysporum & - & - \\
\hline & ITM 4 & P. oxalicum & - & - \\
\hline & ITM 5 & A. tamarii & - & - \\
\hline & ITM 6 & A. niger & - & - \\
\hline & ITM 7 & F. oxysporum & - & - \\
\hline & ITM 8 & F. sacchari & - & - \\
\hline & ITM 9 & F. oxysporum & - & - \\
\hline & ITM 10 & P. citrinum & - & - \\
\hline & ITM 11 & P. citrinum & - & - \\
\hline \multirow{22}{*}{ Aleshinloye Market } & ALH 1 & F. oxysporum & - & - \\
\hline & ALH 2 & F. oxysporum & - & - \\
\hline & ALH 3 & F. sacchari & - & - \\
\hline & ALH 4 & A. tamarii & - & - \\
\hline & ALH 5 & P. citrinum & - & - \\
\hline & ALH 6 & P. citrinum & - & - \\
\hline & ALH 7 & F. compacticum & - & - \\
\hline & ALH 8 & F. oxysporum & - & - \\
\hline & ALH 9 & A. flavus & + & + \\
\hline & ALH 10 & F. solani & - & - \\
\hline & ALH 11 & F. oxysporum & - & - \\
\hline & ALH 12 & Cladosporium sphaerospermum & - & - \\
\hline & ALH 13 & Trichoderma viridae & - & - \\
\hline & ALH 14 & F. compacticum & - & - \\
\hline & ALH 15 & F. compacticum & - & - \\
\hline & ALH 16 & Rhizophus sp. & - & - \\
\hline & ALH 17 & F. verticillioides & - & - \\
\hline & ALH 18 & F. verticillioides & - & - \\
\hline & ALH 19 & F. solani & - & - \\
\hline & ALH 20 & Trichoderma viridae & - & - \\
\hline & ALH 21 & P. oxalicum & - & - \\
\hline & ALH 22 & F. oxysporum & - & - \\
\hline \multirow{23}{*}{ Moniya Market } & MON 1 & A. niger & - & - \\
\hline & MON 2 & Trichoderma viridae & - & - \\
\hline & MON 3 & A. flavus & + & + \\
\hline & MON 4 & A. niger & - & - \\
\hline & MON 5 & A. niger & - & - \\
\hline & MON 6 & A. niger & - & - \\
\hline & MON 7 & A. niger & - & - \\
\hline & MON 8 & A. niger & - & - \\
\hline & MON 9 & Trichoderma viridae & - & - \\
\hline & MON 10 & Alternaria $s p$ & - & - \\
\hline & MON 11 & P. citrinum & - & - \\
\hline & MON 12 & A. niger & - & - \\
\hline & MON 13 & A. niger & - & - \\
\hline & MON 14 & A. niger & - & - \\
\hline & MON 15 & P. chrysogenum & - & - \\
\hline & MON 16 & A. niger & - & - \\
\hline & MON 17 & Rhizophus sp & - & - \\
\hline & MON 18 & F. compacticum & - & - \\
\hline & MON 19 & P. citrinum & - & - \\
\hline & MON 20 & P. oxalicum & - & - \\
\hline & MON 21 & F. oxysporum & - & - \\
\hline & MON 22 & A. flavus & + & + \\
\hline & MON 23 & P. citrinum & - & - \\
\hline
\end{tabular}


Table 5 Detection and quantification of total aflatoxin (ppb) in the smoked-dried frog samples

\begin{tabular}{l|cc}
\hline Source & First sampling & Second sampling \\
\hline Bodija & $8.50^{\mathrm{c}}$ & $3.87^{\mathrm{e}}$ \\
Oja Oba & $8.23^{\mathrm{d}}$ & $2.62^{\mathrm{g}}$ \\
Oje & $8.90^{\mathrm{b}}$ & $3.68^{\mathrm{e}}$ \\
Itamemerin A & $7.40^{\mathrm{f}}$ & $1.86^{\mathrm{h}}$ \\
Itamerin B & $7.72^{\mathrm{e}}$ & $3.04^{\mathrm{f}}$ \\
Aleshinloye A & $6.64^{\mathrm{g}}$ & $3.75^{\mathrm{e}}$ \\
Aleshinloye B & $8.21^{\mathrm{d}}$ & $5.58^{\mathrm{a}}$ \\
Aleshinloye C & $9.17^{\mathrm{a}}$ & $4.44^{\mathrm{d}}$ \\
Moniya A & $5.16^{\mathrm{h}}$ & $4.91^{\mathrm{c}}$ \\
Moniya B & $5.06^{\mathrm{h}}$ & $5.22^{\mathrm{b}}$ \\
\hline
\end{tabular}

Mean values followed by the same lowercase letter(s) along each vertical column are not significantly different by Duncan's Multiple Range Test at $\mathrm{P}<0.05$.

Table 6 Detection and concentration of deoxynivalenol (DON) in the smoked-dried frog samples

\begin{tabular}{l|cc}
\hline Source & $\begin{array}{c}\text { First sampling } \\
(\mathrm{ppm})\end{array}$ & $\begin{array}{c}\text { Second sampling } \\
(\mathrm{ppm})\end{array}$ \\
\hline Bodija & $0.41^{\mathrm{c}}$ & $0.04^{\mathrm{c}}$ \\
Oja Oba & $0.36^{\mathrm{e}}$ & $0.02^{\mathrm{d}}$ \\
Oje & $0.45^{\mathrm{bc}}$ & $0.09^{\mathrm{a}}$ \\
Itamemerin A & $0.48^{\mathrm{b}}$ & $0.06^{\mathrm{b}}$ \\
Itamerin B & $0.40^{\mathrm{cd}}$ & $0.03^{\mathrm{d}}$ \\
Aleshinloye A & $0.48^{\mathrm{b}}$ & $0.00^{\mathrm{e}}$ \\
Aleshinloye B & $0.96^{\mathrm{a}}$ & $0.00^{\mathrm{e}}$ \\
Aleshinloye C & $0.34^{\mathrm{e}}$ & $0.00^{\mathrm{e}}$ \\
Moniya A & $0.00^{\mathrm{f}}$ & $0.00^{\mathrm{e}}$ \\
Moniya B & $0.01^{\mathrm{f}}$ & $0.00^{\mathrm{e}}$ \\
\hline
\end{tabular}

Mean values followed by the same lowercase letter(s) along each vertical column are not significantly different by Duncan's Multiple Range Test at $\mathrm{P}<0.05$.

Table 7 Production and concentration of Aflatoxin by Aspergillus flavus isolated from smoked-dried frog samples

\begin{tabular}{l|ccc}
\hline Source & $\begin{array}{c}\text { Isolate } \\
\text { code }\end{array}$ & $\begin{array}{c}\text { Detection of } \\
\text { Aflatoxin }\end{array}$ & $\begin{array}{c}\text { Concentration } \\
(\mathrm{ppb})\end{array}$ \\
\hline Itamerin A & ITM 1 & + & 1.97 \\
Itamerin B & ITM 2 & + & 1.65 \\
Aleshinloye C & ALH 9 & + & 2.83 \\
Moniya B & MON 22 & + & 3.13 \\
Bodija & BOD 4 & + & 3.56 \\
Moniya A & MON 3 & + & 2.97 \\
\hline
\end{tabular}

+ present, - absent

Table 8 Production and concentration of Deoxynivalenol by Fusarium spp. isolated from smoked-dried frog samples

\begin{tabular}{l|llcc}
\hline Source & $\begin{array}{c}\text { Isolate } \\
\text { code }\end{array}$ & $\begin{array}{c}\text { Fusarium } \\
\text { Isolates }\end{array}$ & DD $^{1}$ & $\mathrm{C}^{2}$ \\
\hline Itamerin A & ITM 3 & F. oxysporum & + & 0.07 \\
Oje & OJE 1 & F. oxysporum & + & 0.05 \\
Aleshinloye A & ALH 1 & F. oxysporum & + & 0.30 \\
Aleshinloye C & ALH 19 & F. solani & + & 0.18 \\
Aleshinloye A & ALH 14 & F. compacticum & + & 0.19 \\
Moniya B & MON 21 & F. oxysporum & + & 0.09 \\
\hline
\end{tabular}

+ present, - absent; $\mathrm{DD}^{1}$ : Detection of Deoxynivalenol; $\mathrm{C}^{2}$ : Concentration (ppm)

Fusarium is another group of field mould with high occurrence in food and feeds. They produce mycotoxins such as deoxynivalenol and zearalenone.

The detection of aflatoxigenic mould in the smokeddried frog samples is in agreement with the work of Guatam et al. (2012) who reported that aflatoxigenic fungi were screened in rice, also with Sekar et al. (2008) in which aflatoxigenic fungi were screened in dried fruits and grains. Kana et al. (2013) also detected aflatoxigenic fungi in food (grains and maize) and poultry feeds. All the Aspergillus flavus isolates in this study were all toxigenic.

The occurrence of aflatoxin in the smoked-dried frog samples may be due to contamination of the frog samples by the toxigenic strains of Aspergillus flavus. Aflatoxin contamination occurs when aflatoxigenic species of Aspergillus flavus group successfully colonize the sample, grow in it and produce aflatoxins as secondary metabolite. Incidence of aflatoxins in other food products such as smoked-dried fish, dried meats, dried yam chips, has been reported as well (Adebayo-Tayo et al., 2008; Makun et al., 2010; Oladejo and Adebayo-Tayo 2011, Akinyemi et al., 2011; Hassan et al., 2011).

The aflatoxin content obtained from the smoked-dried frog samples was higher which is not in agreement with the report of Akinyemi et al., (2011) and Adebayo-Tayo et al (2008) who reported a lower level which was between 0.0301-1.150 ppb and 1.5- 8.1 ppb. The aflatoxins found to be associated with the smoked-dried frog samples sold in different market in Ibadan, were found to be in non-significant levels $(\mathrm{P}<0.05)$ that may be toxic to human health. According to the regulatory levels issued by the Food Drug Administration (FDA) of United States the levels for aflatoxin intake for humans is maximum of $20 \mathrm{ppb}$ (FDA, 2000).

Some samples that were obtained from some markets retailers, such as the Oja Oba, Oje , Aleshinloye A, had the presence of aflatoxin without the isolation of Aspergillus flavus or Aspergillus parasiticus. This is possible as mycotoxins have been reported to be more stable and difficult to eliminate (Rai et al., 2012). The absence of microorganisms is therefore not enough for discarding the presence of toxins. Many studies demonstrated the presence of mycotoxins in commodities without fungal isolation, as for example pulses, cereals and wine (FDA, 2000; Baydar et al., 2005). This means that the presence of fungal strains is not necessary for a food to be potentially dangerous: if those strains produced toxins at some point of their life histories, toxins can last on substrate well after the mycelium has disappeared. Mycotoxins are quite resistant and it is possible they remain chemically stable in stored commodities for long time. It has been shown that they can even survive extreme heating (Tsubouchi et al., 1987), which is an additional problem to food products.

The occurrence of deoxynivalenol (DON) in the smoked-dried frog samples may be due to contamination of the frog samples by the toxigenic strains of Fusarium species. Deoxynivalenol contamination occurs when mycotoxigenic species of Fusarium group successfully colonize the sample, grow in it and produce toxins such as deoxynivalenol, zearalenone as secondary metabolite. The occurrence of deoxynivalenol in other food products such as in rice, wheat and maize have also been reported by (Duverger et al., 2011). The deoxynivalenol produced were between $(0.00-0.96 \mathrm{ppm})$. This was also within the stipulated tolerance limits by the FDA of a maximum of 
$1.0 \mathrm{ppm}$. Some of the samples were shown not to have Deoxynivalenol. Bewaji and Bababunmi (2001), also reported that zearalenone which is another mycotoxin produced by Fusarium species was not detected in Nigerian food stuffs.

In this research all the Aspergillus flavus isolates were aflatoxigenic in nature. The concentration ranged from 1.65-3.56 ppb. This report is in agreement with the work of (Kana et al., 2013).

Table 9 shows the proximate composition of the smoked dried frog samples. The crude protein content of the samples ranged from $40.79-53.98 \%$, in which the highest was recorded in Itamerin B while the least was recorded in Moniya B. There was no crude fibre content recorded in the smoked dried frogs' samples. The crude fat in the smoked dried frogs' samples ranged from 7.30 $13.49 \%$ in which the highest was recorded in Moniya A while the least was recorded in Itamerin B. The crude ash ranged from $12.14-25.14 \%$. The highest was recorded in Aleshinloye $\mathrm{C}$ while the lowest was recorded in Moniya A. The moisture content of the frog samples ranged from $12.44-13.70 \%$. The highest was recorded in Itamerin A while the least was recorded in Moniya B. The carbohydrate content in the frog samples ranged from $5.68-19.20 \%$. The highest was recorded in Aleshinloye A while the least was recorded in Moniya A.

The smoked-dried frog samples had different levels of mineral composition as shown in Table 10. The percentage potassium content ranged from 217.85$1235.83 \mathrm{mg} / 100 \mathrm{~g}$. The highest was recorded in Moniya A while the lowest was recorded in Aleshinloye C.

The calcium content in the smoked-dried frog samples ranged from 4201-437.25 mg/100 $\mathrm{g}$ in which the highest was recorded in Moniya B while the lowest was recorded in Aleshinloye $\mathrm{C}$. The magnesium content in the smoked dried frog samples ranged from 425.83-134 mg/100 g, the highest was recorded in Moniya B while the lowest was recorded in Aleshinloye C.

The iron content of the smoked-dried frog samples ranged from $431.75-1065.0 \mathrm{mg} / 100 \mathrm{~g}$, the highest was recorded in Moniya B while the lowest was recorded in Aleshinloye B.

The lead content in the frog samples ranged from $1.40-11.5 \mathrm{mg} / 100 \mathrm{~g}$, the highest was recorded in Itamerin $\mathrm{B}$ while the lowest was recorded Moniya B. The cadmium content for the smoked-dried frog samples ranged from 0.00-0.22 mg/100 g, the highest was recorded in Moniya $\mathrm{A}$ and there was no cadmium content other than Moniya B. The zinc content in the smoked-dried frog samples ranged from 9.43-5.20 $\mathrm{mg} / 100 \mathrm{~g}$, the highest was recorded in Oja Oba while the lowest was Itamerin B. The copper content ranged from 7.05-18.58 mg/100 $\mathrm{g}$ the highest was recorded in Itamerin A while the lowest was recorded in Aleshinloye C (Table 10).

Table 9 Proximate composition (\%) of smoked-dried frogs sold in Ibadan

\begin{tabular}{l|cccccc}
\hline Parameter & MC & CP & CF & CFB & ASH & CHO \\
\hline Bodija & $14.40^{\mathrm{d}}$ & $45.02^{\mathrm{f}}$ & $10.40^{\mathrm{d}}$ & 0.00 & $13.48^{\mathrm{g}}$ & $16.70^{\mathrm{d}}$ \\
Oja Oba & $14.89^{\mathrm{b}}$ & $43.05^{\mathrm{i}}$ & $10.29^{\mathrm{e}}$ & 0.00 & $15.44^{\mathrm{d}}$ & $16.33^{\mathrm{d}}$ \\
Oje & $13.70^{\mathrm{e}}$ & $44.29^{\mathrm{g}}$ & $8.78^{\mathrm{f}}$ & 0.00 & $15.47^{\mathrm{d}}$ & $17.76^{\mathrm{c}}$ \\
Itamerin A & $16.31^{\mathrm{a}}$ & $45.90^{\mathrm{e}}$ & $12.18^{\mathrm{b}}$ & 0.00 & $13.69^{\mathrm{f}}$ & $11.92^{\mathrm{f}}$ \\
Itamerin B & $14.65^{\mathrm{c}}$ & $52.39^{\mathrm{b}}$ & $7.30^{\mathrm{i}}$ & 0.00 & $15.54^{\mathrm{d}}$ & $10.11^{\mathrm{g}}$ \\
Aleshinloye A & $14.92^{\mathrm{b}}$ & $43.63^{\mathrm{h}}$ & $7.63^{\mathrm{g}}$ & 0.00 & $14.62^{\mathrm{c}}$ & $19.20^{\mathrm{b}}$ \\
Aleshinloye B & $12.44^{\mathrm{g}}$ & $47.79^{\mathrm{c}}$ & $8.79^{\mathrm{f}}$ & 0.00 & $17.28^{\mathrm{b}}$ & $13.86^{\mathrm{e}}$ \\
Aleshinloye C & $12.82^{\mathrm{f}}$ & $47.35^{\mathrm{d}}$ & $7.37^{\mathrm{h}}$ & 0.00 & $25.14^{\mathrm{a}}$ & $7.31^{\mathrm{h}}$ \\
Moniya A & $14.92^{\mathrm{b}}$ & $53.98^{\mathrm{a}}$ & $13.49^{\mathrm{a}}$ & 0.00 & $12.14^{\mathrm{h}}$ & $5.68^{\mathrm{i}}$ \\
Moniya B & $11.58^{\mathrm{h}}$ & $40.79^{\mathrm{j}}$ & $11.19^{\mathrm{c}}$ & 0.00 & $16.62^{\mathrm{c}}$ & $19.82^{\mathrm{a}}$ \\
\hline
\end{tabular}

Mean values followed by the same lowercase letter(s) along each vertical column are not significantly different by Duncan's multiple range test at $\mathrm{P}<0.05$; Key: $\mathrm{MC}=$ Moisture Content, $\mathrm{CP}=\mathrm{Crude}$ Protein, $\mathrm{CF}=\mathrm{Crude}$ Fat, $\mathrm{CFB}=$ Crude Fibre, $\mathrm{ASH}=\mathrm{Ash}, \mathrm{CHO}=\mathrm{Carbohydrate}$

Table 10 Mineral composition (mg/100g) of smoked-dried frogs sold in Ibadan

\begin{tabular}{|c|c|c|c|c|c|c|c|c|}
\hline Parameter & $\mathrm{K}$ & $\mathrm{Ca}$ & $\mathrm{Mg}$ & $\mathrm{Fe}$ & $\mathrm{Pb}$ & $\mathrm{Cd}$ & $\mathrm{Zn}$ & $\mathrm{Cu}$ \\
\hline Bodija & $306.50^{i}$ & $470.75^{\mathrm{h}}$ & $167.50^{\mathrm{ef}}$ & $810.25^{\mathrm{b}}$ & $7.00^{\mathrm{d}}$ & $0.00^{\mathrm{c}}$ & $8.17^{b}$ & $11.45^{\mathrm{e}}$ \\
\hline Oja Oba & $580.25^{\mathrm{g}}$ & $779.75^{\mathrm{e}}$ & $177.50^{\mathrm{de}}$ & $604.25^{\mathrm{c}}$ & $10.00^{\mathrm{b}}$ & $0.00^{\mathrm{c}}$ & $9.43^{\mathrm{a}}$ & $15.63^{b}$ \\
\hline Oje & $1224.65^{b}$ & $710.00^{f}$ & $206.25^{c}$ & $540.50^{\mathrm{d}}$ & $9.00^{c}$ & $0.00^{\mathrm{c}}$ & $7.85^{\mathrm{b}}$ & $18.58^{\mathrm{a}}$ \\
\hline Itamerin A & $550.93^{\mathrm{h}}$ & $694.50^{\mathrm{g}}$ & $187.00^{\mathrm{d}}$ & $545.00^{\mathrm{d}}$ & $5.75^{\mathrm{e}}$ & $0.00^{\mathrm{c}}$ & $6.73^{c}$ & $16.10^{\mathrm{b}}$ \\
\hline Itamerin B & $775.90^{f}$ & $814.75^{\mathrm{d}}$ & $146.25^{\mathrm{g}}$ & $439.25^{\mathrm{f}}$ & $11.50^{\mathrm{a}}$ & $0.00^{\mathrm{c}}$ & $5.20^{\mathrm{d}}$ & $14.50^{\mathrm{c}}$ \\
\hline Aleshinloye A & $1149.93^{c}$ & $874.75^{c}$ & $161.13^{f}$ & $474.25^{\mathrm{e}}$ & $9.25^{\mathrm{bc}}$ & $0.00^{\mathrm{c}}$ & $5.33^{\mathrm{d}}$ & $13.00^{\mathrm{d}}$ \\
\hline Aleshinloye B & $851.33^{\mathrm{e}}$ & $787.50^{\mathrm{e}}$ & $215.75^{\mathrm{c}}$ & $431.75^{\mathrm{f}}$ & $7.75^{\mathrm{d}}$ & $0.00^{\mathrm{c}}$ & $7.80^{\mathrm{b}}$ & $13.68^{d}$ \\
\hline Aleshinloye C & $217.85^{\mathrm{i}}$ & $437.25^{\mathrm{i}}$ & $134.25^{\mathrm{h}}$ & $438.25^{\mathrm{f}}$ & $7.00^{\mathrm{d}}$ & $0.00^{c}$ & $5.95^{\mathrm{cd}}$ & $7.05^{\mathrm{g}}$ \\
\hline Moniya A & $1235.83^{\mathrm{a}}$ & $2082.08^{b}$ & $282.17^{\mathrm{b}}$ & $413.33^{\mathrm{g}}$ & $3.10^{\mathrm{f}}$ & $0.22^{\mathrm{a}}$ & $8.10^{\mathrm{b}}$ & $11.50^{\mathrm{e}}$ \\
\hline Moniya B & $925.00^{\mathrm{d}}$ & $4201.67^{\mathrm{a}}$ & $425.83^{\mathrm{a}}$ & $1065.00^{\mathrm{a}}$ & $1.40^{\mathrm{g}}$ & $0.16^{\mathrm{b}}$ & $6.03^{\mathrm{cd}}$ & $8.00^{f}$ \\
\hline
\end{tabular}

Mean values followed by the same lowercase letter(s) along each vertical column are not significantly different by Duncan's multiple range test at $\mathrm{P}<0.05$ 
The mean protein content in the smoked-dried frog samples was high. The high protein content recorded in all the smoked-dried frog samples is in agreement with the report of (Oduntan et al., 2012), who reported similar result. The moisture content was also found to be higher in this study than the findings of (Oduntan et al., 2012). The moisture content of samples indicates that the smoked-dried frog is sufficiently dried to minimize microbial growth. However, high microbial load may be due to moisture absorption from the environment which increases the growth of moulds on the surface. The high ash content may be due to resultant dirt on the frog during drying on the ground in the open market. Torres et al. (1994) reported that ash content at the end of storage differs significantly to that at the onset.

High mineral content was recorded in smoked-dried frog samples obtained from different markets in Ibadan; this report is not in agreement with the work of (Oduntan et al., 2012). The processing was slightly different, when compared to the latter. The heavy metals were relatively low, which indicates less toxicity.

The presence of mineral elements such as potassium, calcium, magnesium, which are important elements; they become constituents of protein, nucleic acid and other cell components. Calcium are essential elements found in human bones, iron and magnesium are essential trace elements which play vital part in the metabolic processes that take place in human system and blood regulation. In some enzymatic activities magnesium also functions as co-factor. Zinc is a vital mineral required for humans, with $10 \mathrm{mg} /$ day and $15 \mathrm{mg} /$ day as the recommended daily allowance for humans and children respectively (NAS NRC. 1974). Sanstead (1976) reported that zinc has a protective effect against the intoxication of lead and cadmium. The inadequacy of zinc could lead to retarded growth, loss of taste and decrease in fertility.

There was detection of lead in all the samples, and the concentration was between $1.40-11.50 \mathrm{mg} / 100 \mathrm{~g}$, lead causes renal failure and liver damage. Cadmium concentration in the smoked-dried frog samples $(0.00-$ $0.22 \mathrm{mg} / 100 \mathrm{~g}$ ) was below the standard limit of FAO (1981). Ingestion of food containing cadmium leads to exposure, which could lead to severe symptoms and sometimes renal failure (NAS - NRC. 1982). Copper is an essential part of several enzymes and it is necessary for the synthesis of haemoglobin, copper was detected in all the samples. When copper is ingested beyond $350 \mathrm{mg}$ it could lead to shock and acute renal failure (NAS - NRC. 1982).

The implication of this study is that smoked-dried frogs sold in markets in Ibadan are contaminated with mycotoxigenic fungi and mycotoxins. Therefore it is likely that the consumers of the smoked dried frog would have been taking partially unhealthy food, especially since some the consumers are also illiterate who consume the frog without adequate processing at the point of purchase. Although, in very small amount, prolonged intake of these mycotoxins may constitute health hazard. Some of the moulds isolated are probably contaminants in the frog samples, better methods of preservation will reduce their incidence or eliminate them.

\section{Conclusion}

In conclusion smoked-dried frogs sold in markets in Ibadan are contaminated with mycotoxigenic fungi and mycotoxins which is of public health concern.

\section{References}

AOAC. 1990. Official methods of analysis $15^{\text {th }}$ Ed. Association of official Analytical Chemist Washington DC, USA..

Adebayo-Tayo BC, Onilude AA, Patrick UG. 2008. Mycofloral of smoked-Dried Fishes Sold in Uyo, Eastern Nigeria. World J. Agricul. Sci.., 4:3, 346-350.

Akinyemi AA, Adejola AQ, Obasa SO, Ezeri GNO. 2011. Aflatoxins in smoked-dried fish sold in Abeokuta, Ogun State, South-west Nigeria; proceedings of the Environmental Management Conference, Federal University of Agriculture, Abeokuta,

Atanda OO, Akpan I, Enikuomehin OA. 2006. Palm kernel agar: An alternative culture medium for the rapid detection of aflatoxins in agricultural commodities. African J. Biotechnol., 5: 10, 1029-1033.

Bankole SA, Adebanjo A. 2003. Mycotoxins in food in West Africa: current situation and possibilities of controlling it. African J. Biotechnol.. 2: 9, 254-263.

Bankole SA. 1994. Changes in moisture content, fungal infection and kernel germ inability of maize in storage. International J. Tropical Plant Dis., 12: 213-218.

Barbosa TS, Pereyra CM, Soleiro CA, Dias EO, Oliveira AA, Keller KM, Silva POP, Cavaglieri LR, Rosa CAR. 2013. Mycobiota and mycotoxins present in finished fish feeds from farms in the Rio de Janeiro State. Brazilian International Aquatic Res., 5: 3, $1-9$.

Baydar T, Engin AB, Girgin G, Aydin S, Sahin G. 2005. Aflatoxin and ochratoxin in various types of commonly consumed retail ground samples in Ankara, Turkey. Annals of Agricul. Environ. Med., 12: 193-197.

Bewaji CO, Bababunmi EA. 2001. Mycotoxins in Nigerian foodstuffs. Nigerian Society for Experimental Biol., 1: 4, 361365.

Bhat RV, Vasanthi S. 2003. Food Safety in Food Security and Food Trade: Mycotoxin Food Safety Risk in Developing Countries. Washington D.C. International Food Policy Research Institute, (Brief).

Blesa J, Soriano JM, Moltó Mañes J. 2004. Concentration of ochratoxin A in wines from supermarkets and stores of Valencian Community (Spain). J. Chromatography A. 1054: 397-401.

Bucci, T, Kansen DK, Labord JB. 1990. Leukoencephalomalacia and haemorrhage in the brain of rabbits gavaged with mycotoxins Fumonisin B1 Food Chem., 38: 1900-1903.

Davis ND, Iyer SK, Diener UL. 1987. Improved Method of screening for Aflatoxin with a Coconut Agar Medium. Appl. Environ. Microbiol., 53: 1593-1595.

Domsch KH, Gams W. 1980 Compendium of soil fungi. TrauteHeidi Anderson Institute of Soil Biology Federal Agricultural Research Centre Braunschweig, Federal Republic of Germany. Vol 1. Academic Press (London) LTD, Pp 105-524.

Duverger F, Bailly S, Querin A, Pinson-Gadais L, Guerre P, Bailly JD. 2011. Influence of culture medium and incubation time on the simultaneous synthesis of Deoxynivalenol and zearalenone by Fusarium graminearum. Revenue Medical and Veterinary. 162: 2, 93-97.

Eyo AA. 1992. Traditional and improved fish handling, preservation and processing techniques. NAERLS/NIFER national workshop on fish processing, storage, marketing and utilization, pp: 15 .

FAO. 1981. Compilation of Legal Limits for hazardous Substance in fish and fishery Products (Food and Agricultural Organization). FAO Fishery Circular, 464: 5-100. 
Food and Drug Administration. 2000. Conference on mycotoxins in animal feeds, grains and food related to human and animal health. Rockville, Maryland.

Gautam AK, Gupta H, Soni Y. 2012. Screening of fungi and mycotoxins associated with stored rice grains in Himachal Pradesh. International J. Theoretical and Appl. Sci., 4: 2, 128133.

Hassan AA, Hassan AM, El-Shafei HM, El- Ahl MHSR, Abd ElDayem, RH. 2011. Detection of Aflatoxigenic Moulds Isolated From Fish and their Products and its Public Health Significance. Nature and Sci., 9: 9, 106-114.

Jonathan SG, Esho EO. (2010). Fungi and Aflatoxin detection in two oyster mushrooms Pleurotus ostreatus and Pleurotus pulmonarius from Nigeria. Electronic Journal of Environmental, Agricul. Food Chem.., 9: 11, 1722-1730.

Jonathan SG, Abdul-Lateef MB, Ayansina ADV. 2013. Fungal and aflatoxin detection in fresh and stored 'garri ijebu' (locally processed food). Report and Opinion. 5: 2, 13-19.

Kaaya AN, Kyamuhangire W, Kyamanywa S. (2006). Factors affecting aflatoxin contamination of harvested maize in the three agro-ecological zones of Uganda. J. Appl. Sci.,.6: 24012407.

Kana RK, Gnonlonfin BGJ, Harvey J, Wainaina J, Wanjuki I, Skilton RA, Teguia A. 2013. Mycobiota and Toxigenicity profile of Aspergillus flavus Recovered from Food and Poultry Feed Mixtures in Cameroon. J. Animal and Poultry Sci., 2: 4, 98-107.

Lee NA, Wang S, Allan RD, Kennedy IR. 2004. A Rapid Aflatoxin $B_{1}$ ELISA: Development and Validation with Reduced Matrix Effects for Peanuts, Corn, Pistachio and Soybeans. J. Agricul. Fd. Chem.., 52: 2746-2755

Makun HA, Anjorin ST, Moronfoye B, Adejo FO, Afolabi OA. 2010. Fagbayibo, G., Balogun, B.O., and Surajudeen, A.A. Fungal and aflatoxin contamination of some human food commodities in Nigeria. African J. Fd. Sci.., 4: 4, 127-135.

Mohneke M, Onadeko AB, Rodel MO. 2009. Exploitation of frogsa review with a focus on West Africa. Salamandra. 45: 193203.

NAS - NRC. 1974. National Academy of Sciences. National Research Council. Food and Nutrition Board Recommended Dietary Allowances. Washington DC. National Academic Press.

NAS - NRC. 1982. National Academy of Sciences. National Research Council. Drinking water and Health (Vol.4) Washington DC: National Academic Press.
Oduntan OO, Akintunde OA, Oyatogun MOO, Shotuyo ALA, Akinyemi AF. 2012. Proximate Composition and Social Acceptability of Sun-Dried Edible Frog (Rana esculenta) in Odeda Local Government Area, Nigeria. Patnsuk J. Agricul. Technol.. 8: 1, 134-143.

Oladejo DA, Adebayo-Tayo BC. (2011). Moulds, Proximate Mineral Composition and Mycotoxin Contamination of Banda ("kundi/tinko") sold in Ibadan, Oyo State, Nigeria. Assumption University J. Technol., 15: 1, 32-40.

Onions AHS, Allsopp D, Eggins HOW. 1981. Smiths Introduction to Industrial Mycology. Edward Arnold, London, pp: 398.

Pelczar MJ, Chan ECS, Krieg KR. 1993. Microbiology concepts and applications, Mcgraw - Hill, New York.

Pitt JL, Basilico JC, Abarca ML, Lopez C. 2000. Mycotoxins and toxigenic fungi. Medical Mycology. 38: 41-46.

Rai MK, Bonde SR, Ingle AP, Gade AK. 2012. Mycotoxin: Rapid detection, differentiation and safety. J. Pharmaceutical Education and Research. 3: 1, 22-34.

Raper KB, Fennell DI. 1965. The Genus Aspergillus. Williams and Wilkins co, Baltimore, pp 1-686.

Sanstead, HH. 1976. Interaction of cadmium and lead with essential minerals. In; G.F. Nordberg (Ed.), Effects and Dose- Response Relationships of Toxic Metals,511-520. Amsterdam: Elsevier.

Sekar P, Yumnam N, Ponmurugan K. 2008. Screening and Charecterization of Mycotoxin producing fungi from dried fruits and grains. Adv. Biotechnol., 12: 15.

Singh K, Frisvad JC, Thrane U, Mathur SB. 1991. An Illustrated Manual on Identification of some Seed-borne Aspergilli, Fusaria, Penicillia and their mycotoxins. Danish Government Institute of seed pathology for developing countries.

Somorin YM, Bankole SA. 2010. Mycoflora of stored "Ofada" and "Abakaliki" rice in Lagos and Ogun States, South western Nigeria. African J. Microbiol,. 4: 16, 1724-1726.

Torres, E.A.F.S., Shimokomaki, M., Franco, B.D.G.M. and Landgrant, M. 1994. Parameter determining the quality of Charqui an Intermediate Moisture Meat product. Meat Sci., 38: 229-234.

Tsubouchi H, Yamamoto K, Hisada K, Sakabe Y, Udagawa S. 1987. Effect of roasting on ochratoxin A level in green coffee beans inoculated with Aspergillus ochraceus. Mycopathologia, 97: 2, 111-115.

Wiley JM, Sherwood LM, Woolverton CJ. 2008. Fungi. In: Prescott, Harley and Klein's Microbiology. $7^{\text {th }}$ Edition. McGRaw-Hill Companies, inc., New York, Pp 629-630. 